\title{
An Exploratory Case Study on the Metrics and Performance of IoT Investment in Japanese Manufacturing Firms
}

\author{
Mitsuhiro Fukuzawa ${ }^{1, *(\mathbb{D}}$, Ryosuke Sugie ${ }^{2}$, Youngwon Park ${ }^{2}$ and Jin $\mathrm{Shi}^{2}$ \\ 1 Faculty of Business Administration, Seikei University, 3-3-1 Kichijoji-Kitamachi, Tokyo 1808633, Japan \\ 2 Graduate School of Humanities and Social Sciences, Saitama University, 255 Shimo-Okubo, Sakura-ku, \\ Saitama 3388570, Japan; rsk.sugie@gmail.com (R.S.); ywparkjp@gmail.com (Y.P.); \\ shijin@mail.saitama-u.ac.jp (J.S.) \\ * Correspondence: mfukuzawa@bus.seikei.ac.jp
}

Citation: Fukuzawa, M.; Sugie, R.; Park, Y.; Shi, J. An Exploratory Case Study on the Metrics and

Performance of IoT Investment in Japanese Manufacturing Firms.

Sustainability 2022, 14, 2708. https:// doi.org/10.3390/su14052708

Academic Editor: Jurgita Antuchevičienè

Received: 29 December 2021 Accepted: 23 February 2022 Published: 25 February 2022

Publisher's Note: MDPI stays neutral with regard to jurisdictional claims in published maps and institutional affiliations.

Copyright: (C) 2022 by the authors. Licensee MDPI, Basel, Switzerland. This article is an open access article distributed under the terms and conditions of the Creative Commons Attribution (CC BY) license (https:// creativecommons.org/licenses/by/ $4.0 /)$.

\begin{abstract}
This study investigates the objectives, approval process, decision criteria, metrics, and performance of the Internet of Things (IoT) system investment in four Japanese manufacturing firms through exploratory case analysis. This study conducted semi-structured interviews and several workshops with practitioners to collect, confirm, supplement, and verify the interviews data and the researcher's interpretations. The study clarifies the actual status of investment activities in IoT systems and the essential common issues. In addition, this study shows that IoT investments in Japanese companies improve production activities' efficiency. However, collaboration among divisions and departments other than production is not sufficient. This paper also contributes to constructing an analytical framework for comprehensively clarifying IT system investment decisionmaking and investment effects. These findings will be one of the reference points of the IoT system investment project and will contribute to the recent digital transformation movement in many manufacturing firms.
\end{abstract}

Keywords: IoT investment; IT investment; metrics of information system investment; Industry 4.0; Smart Factory; advanced manufacturing technology; digital transformation; lean management; Japanese company; case study

\section{Introduction}

Natural disasters and infectious diseases can cause production activities and supply chain disruptions [1-5]. More recently, the spread of COVID-19 has had a significant impact on the sustainability of global supply chains, as the movement of people and goods has been severely restricted, resulting in the stoppage or reduction of production activities in factories [6,7]. Furthermore, in some countries and regions, including Japan, as the birthrate is declining and the population is aging, the long-term trend is for the number of workers supporting factories and supply chains to decline. In this situation, it will not be easy to continue production activities and supply chain operations that rely heavily on manual labor while increasing productivity.

As described above, dynamic environmental factors such as natural disasters, the spread of infectious diseases, and the decline in the working population significantly impact the sustainability of manufacturing and global supply chains. In order to prepare for and adapt to these events, automation and digitalization in factories and operations will be an effective way. In other words, the successful implementation of IoT, digitalization of operations, and smart factories are essential for improving the sustainability of manufacturing and global supply chains.

In recent years, digital technologies have been used in various activities ranging from production to development and sales [8-10]. For example, the "Internet of Things (IoT)", an IT system mainly targeted at the production floor, significantly impacts the design information flow inside the factory and the entire supply chain. The IoT has been 
positioned as one of the critical enablers of Industry 4.0 and smart factories [11-17]. This technology serves as a critical support tool to facilitate effective measurement, visualization, storage, and utilization of "genba" (field) data and improve operational performance.

In these contexts, the excellence of decision-making about IoT system investment greatly influences the Japanese firms' manufacturing capabilities and competitive advantage. However, empirical analysis on the purpose of investment in IoT, the actual state of the decision-making process of "IoT system investment" inside the factory, and those metrics and performance have not been sufficiently investigated [8-20].

The present study aims to clarify the actual status and issues of IoT system investment in Japanese companies. For this purpose, this paper conducted an exploratory comparative case study analysis [21] of IoT investment activities in Japan, focusing on four Japanese manufacturing sites. The cases discussed are mainly IoT systems used in manufacturing sites and include IT systems used in multiple factories, supply management systems, and other IT systems that facilitate the digitization of supply chains and engineering chains. In this paper, the term "IoT investment" means the decision-making process for implementing IoT in factories and the realized IoT system. The case studies were collected through interviews with practitioners, workshops, and secondary sources. The research questions are as follows: (1) What is the actual state of IoT system investment in Japanese companies? (2) What challenges do these firms face? What are the common (or unique) issues of each company?

\section{Literature Review}

\subsection{Focus of Research on Digitalization of Operations and Supply Chains}

There has been considerable research on the digitization of operations and supply chains in recent years, with special issues of journals in the operations and supply chain management fields devoted to this topic [8-10]. There have been many systematic and bibliometric reviews on topics such as Smart Factory, Industry 4.0, and IoT since the late 2010s [11-18,22-34]. Furthermore, some studies have conducted questionnaires on researchers' perceptions around the world on the research topic of Industry 4.0 [11]. This paper will not conduct another comprehensive systematic review of these topics, because there are numerous review studies of existing research published up to the late 2010s. These review articles cover studies on the digitization of production sites and supply chains. According to these papers, research on the digitalization of existing operations and supply chains has focused on the actual status of Industry 4.0 and Smart Factory, the use of advanced technologies, and the performance of Smart Factory and Industry 4.0.

The core phenomena and keywords covered by the above review articles can be classified into three main categories: Industry 4.0, IoT, and Smart Factory. The most significant number of review articles are published on existing research related to Industry 4.0 [12-18,22-31]. Some papers broadly review prior research on Industry 4.0 as a research theme in business administration and operations management [12-16], papers that review prior research on the use of technology to realize Industry $4.0[17,22-24]$, and papers that review Industry 4.0 initiatives in small and medium-sized enterprises (SMEs) [25]. In addition, there are review papers that focus on the relationship between lean production and lean practices and Industry 4.0 and digitalization [26-28].

There are also review articles that focus on the concept of Smart Factory and how it is being globally expanded and utilized [29], and review papers that specifically focus on Smart Factory as a key concept in Industry 4.0 [30]. In addition, the paper reviews existing IoT-related research, mainly on the themes of the impact of IoT use on supply chain management and the impact of IoT on business models [31-34].

Based on many of these review articles, the following can be suggested.

(1) Practices and academic research on the digitalization of operations and supply chain, IoT technology advancement, Industry 4.0, and Smart Factory have progressed rapidly over the past decade $[8-18,22-34]$. Therefore, empirical analysis of the actual state 
of investment and utilization of IoT and IT systems in Japanese companies is effective in attracting attention from practitioners and academics.

(2) Researchers need to keep in mind that digital technologies can be applied in a wide range of subjects and areas, such as IoT, DX, Industry 4.0, Smart Factory, and manufacturing servitization. Some studies focus on automation and digitalization in individual production processes $[18,20]$, while others focus on the digitalization of entire factories [18,22-24], and others focus on the technologies to realize the Smart Factory $[29,30]$. There is also research on digitalization in the supply chain and the servitization of manufacturing [31-34].

(3) The existing research is not limited to large companies but also includes small and medium-sized companies [25]. There is a wide range of countries and regions studied, including North and South America, Australia, Europe (Germany, France, etc.), and emerging countries (China, India, etc.) [11-18,24]. However, these review articles reveal that little research has been conducted on Japanese companies [11-18,24]. Thus, it can be said that, at least in English-language journals, the actual situation of IoT investment decisions and implementation and Smart Factory in Japanese companies has not been sufficiently clarified. In this respect, empirical analysis of digitalization in Japanese companies will have significant contributions. In addition, analyzing the actual status of IoT implementation and digitalization in Japanese factories with high lean manufacturing capability $[35,36]$ will also clarify the relationship between lean practices and factory digitalization [26-28].

\subsection{Empirical Research on the Relationship between Industry 4.0/Smart Factory and Organizational Capabilities}

This paper focuses on the existing empirical research on the relationship between Industry 4.0 and Smart Factory and the digitization of operations, practices, and organizational capabilities in factories and supply chains [37-59]. The empirical studies on the relationship between digitalization of production sites and supply chains and lean management conducted by researchers in Western countries can be summarized as follows.

(1) The impact of the introduction of advanced manufacturing technology, enabling technologies for Industry 4.0 (e.g., IoT and manufacturing execution system), and enterprise information systems (ERP) on lean practices and operational performance [37-51]. The impact of lean implementation on the relationship between advanced technology adoption and operational performance [52-56].

(2) The impact of the use of IoT on supply chain management and the servitization of manufacturing firms [57-59].

(3) Research on performance measurement systems in highly digitalized factories [60-63]. These studies have provided valuable insights into the validity and effectiveness of performance measurement methods and indicators. However, these studies have focused on Western companies, and there has been insufficient research on what evaluation indicators are used and their effectiveness in Japanese companies, which have been thoroughly promoting lean production.

These empirical studies have mainly focused on companies in Western countries. There are relatively few studies on Japanese companies, which can be the origin of lean manufacturing [35,36]. The scholars [19] conducted some case studies on information systems in a Japanese manufacturing company. The study clarifies how the IT system supports and improves the flow of materials and information in development and production activities. The scholars [19] discuss the characteristics of IT systems that are effective in realizing and supporting the "good flow of good design", and how to build IT systems that enable the flow of design information and management information to flow smoothly throughout the value chain without falling into partial optimization.

Furthermore, in a study on the IoT and IT systems in Japanese companies [20], the actual status of digitization of the value chain and the factors that promote or hinder it are clarified from the perspective of the degree of information integration. One of the most important findings is that although information technology has improved the flow of materials and information in production activities, there are still problems in coordination 
among departments, functions, and companies. For example, because the company's IT system is not sufficiently integrated across departments, even if the same IT system is used, the way it is operated differs among departments [20].

These empirical studies of Japanese companies $[19,20]$ have the limitation that they do not sufficiently clarify the actual status of IT system investment. Furthermore, although the IoT systems used in the factory have been identified, the purpose of investment in the systems, investment decision-making, evaluation criteria, and results have not been sufficiently clarified.

\subsection{Research on the Performance and Decision-Making of Information System Investment}

In the management information systems research, empirical analysis of information system investment and its performance has been conducted. In particular, RBV (resource based view) as a theoretical background, research has been conducted to aggregate the amount of investment in IT systems at the firm level and clarify the relationship between such investment and firm performance [64-68]. Financial results (e.g., profit, ROI) have been mainly used as corporate performance. These studies that analyze IT investment activities aggregated at the corporate level have not sufficiently clarified actual IT investment activities' evaluation criteria and effectiveness of indicators. The scholars [69] argue that it is not easy to accurately measure the effect of IT investment without considering the actual state of IT use. Although research on the effects of an investment in information systems used in factories has been conducted focusing on the factory level [52-54,70,71], the accumulation of research is not sufficient.

In the research area of management information systems, much research has focused on the decision-making of information system investment. In particular, some studies have analyzed information system investment decisions using real options theory, focusing on the valuation of investment projects [72-75]. However, what is essential in evaluating IT investment at the factory is clarifying what evaluation criteria are actually used there. It should be clarified how the effectiveness of IT systems is actually evaluated before and after the investment.

Furthermore, some studies reveal the details of the decision-making process for information system investment [76-83]. Based on qualitative or quantitative analysis, these studies clarify the details and structural characteristics of IT governance and decisionmaking processes. However, these studies have not clarified what evaluation criteria are used to make decisions on investments in IT systems that enable manufacturing companies to improve their capabilities and performance. In addition, the relationship between such investment behavior in IT systems and performance in production activities has not been sufficiently clarified. As described above, the limitation of existing research is that comprehensive empirical analysis covering the entire process from IT system investment decision-making to the realization of factory performance has not been conducted.

\subsection{Research Gaps in Existing Studies and the Focus of This Paper}

In recent years, the rapid digitization of production activities and supply chains has increased the need for a detailed analysis of the actual decision-making and evaluation criteria for investment in digital technologies. However, existing studies have not sufficiently clarified the actual state of IoT investment decision-making and implementation, which are essential in realizing such digitalization [76-83]. It is also necessary to analyze the relationship between IoT implementation and organizational capabilities in production sites [52-56,60-63,70,71].

Furthermore, detailed empirical studies targeting Japanese companies have not been sufficiently conducted $[19,20]$, which can be considered one of the limitations of existing research. Therefore, it is necessary to conduct empirical research that focuses on how digitalization will progress in Japanese manufacturing sites, which have achieved a relatively high level of leanness. In other words, it is crucial to clarify how the decision-making and 
evaluation of an investment in digital technology are carried out and what issues arise in the process when further promoting digitalization in the high-level lean factories [26-28,35-51].

Based on the findings of existing research, the research objectives of this paper are as follows. In order to clarify how digital technology should be evaluated and introduced in Japanese companies, which have accumulated and evolved highly lean manufacturing capabilities when trying to promote digitization more than ever. This paper conducts an exploratory case study on the purpose of investment in IoT systems, evaluation criteria for investment, and investment outcomes. One of the expected practical contributions of this paper is to provide a point of reference for answering the "practitioner's question" that "we know that investment in digital technology is essential, but we are not sure how it will be helpful".

\section{Methodology}

The present study conducted an exploratory case study of IoT system investment activities centered on multiple manufacturing sites in Japan. An exploratory case study has a legitimate reason when the researchers do not have any propositions, have little or no control over behavioral events, and the research focus is a contemporary phenomenon [21]. This type of case study is suitable for fact-finding and theory-building [84].

Four Japanese manufacturing companies (from Company A to Company D) that have global factories were selected as case firms based on the following considerations: (1) They are all representative Japanese firms with high brand recognition and advanced manufacturing systems; (2) They are all multinational enterprises running businesses on a global scale, which means their operations management issues are complex; (3) All the firms are developing broad product portfolios, implying that they have various production demands. Table 1 presents an overview of the studied companies. All factories investigated in this case study were located in Japan. Each company is a large Japanese company representing its respective industry, with a long history, many employees, and a large number of sales. The cases showed in this paper could be used as a reference for many other companies as they are advanced to digitize and utilize IoT in their factories and supply chains. The cases are mainly IoT systems used in manufacturing sites and include IT systems used in multiple factories, supply management systems, and other IT systems that promote the digitization of supply chains and engineering chains.

We obtained responses from each company regarding their IoT system investment activities in the last five years. We conducted semi-structured interviews with senior managers responsible for production management and information system investment at the case firms. Table 2 shows the research focus and items used in these interviews. The interviews were undertaken several times from 2019 to 2021, and each lasted one to two hours. All interviews were recorded and transcribed within twenty-four hours, then the content was checked for correctness by the authors and interviewees. Furthermore, based on the information obtained therein, several workshops were conducted with the participation of practitioners and academics to confirm, supplement, elaborate, and verify the interview data and our interpretations. In addition, the information was supplemented based on publicly available information from companies and secondary sources. Table 3 summarizes the research procedure in this paper. 
Table 1. Overview of the studied companies.

\begin{tabular}{|c|c|c|c|c|}
\hline & Company A & Company B & Company C & Company D \\
\hline Main products & $\begin{array}{l}\text { Chemical materials } \\
\text { Medical devices }\end{array}$ & $\begin{array}{c}\text { Inverter } \\
\text { Power generators }\end{array}$ & Car audio & $\begin{array}{c}\text { Factory automation } \\
\text { devices }\end{array}$ \\
\hline $\begin{array}{c}\text { Sales } \\
\text { (FY2021, consolidated, } \\
\text { approximate number, } \\
\text { JPY) }\end{array}$ & 2000 billion & 800 billion & 250 billion & 600 billion \\
\hline $\begin{array}{l}\text { Employees } \\
\text { (FY2021, consolidated, } \\
\text { approximate number) }\end{array}$ & 70,000 & 25,000 & 10,000 & 28,000 \\
\hline Main transactions & $\begin{array}{c}\text { B to B } \\
\text { (Partly B to C) }\end{array}$ & B to $B$ & $\begin{array}{c}\text { B to B } \\
\text { (Partly B to C) }\end{array}$ & B to $B$ \\
\hline $\begin{array}{l}\text { Features of } \\
\text { Supply chain }\end{array}$ & $\begin{array}{l}\text { Parts and materials are } \\
\text { transported from } \\
\text { suppliers to equipment } \\
\text { production factories, } \\
\text { assembly factories, and } \\
\text { final goods are stored } \\
\text { in ware- } \\
\text { houses / distribution } \\
\text { centers. } \\
\text { Final products are } \\
\text { transported to sales } \\
\text { agents or directly sold } \\
\text { to end-users. }\end{array}$ & $\begin{array}{l}\text { Parts and materials are } \\
\text { transported from } \\
\text { suppliers to equipment } \\
\text { production factories, } \\
\text { assembly factories, and } \\
\text { final goods are stored } \\
\text { in ware- } \\
\text { houses / distribution } \\
\text { centers. } \\
\text { Final products are } \\
\text { transported to sales } \\
\text { agents or directly sold } \\
\text { to end-users. }\end{array}$ & $\begin{array}{l}\text { Parts and materials are } \\
\text { transported from } \\
\text { overseas factories or } \\
\text { subcontractors to } \\
\text { finished goods } \\
\text { factories, warehouses, } \\
\text { and distribution } \\
\text { centers. } \\
\text { Final products are } \\
\text { distributed to sales, } \\
\text { agencies, and } \\
\text { automobile } \\
\text { manufacturers. }\end{array}$ & $\begin{array}{l}\text { Parts and materials are } \\
\text { transported from } \\
\text { suppliers to equipment } \\
\text { production factories, } \\
\text { assembly factories, and } \\
\text { final goods are stored } \\
\text { in ware- } \\
\text { houses / distribution } \\
\text { centers. } \\
\text { Final products are } \\
\text { transported to sales } \\
\text { agents or directly sold } \\
\text { to end-users. }\end{array}$ \\
\hline
\end{tabular}

Table 2. Research focus and interview items.

\section{Research Focus}

Overview of the IoT system
Items

Objectives of IoT system

Characteristics of IoT system

Application/ implementation area

The approval process for IoT system investment

Proposer and drafter of IoT investment Hierarchy/ position of proposer and drafter

Decision criteria of IoT investment

Quantitative and qualitative criteria used in investment decision making

Metrics of IoT investment performance

Measurement and verification of quantitative and qualitative effects after investment in IoT system

Table 3. Overview of research procedure.

\begin{tabular}{cccc}
\hline $\begin{array}{c}\text { Month/Year of } \\
\text { Interview or Workshop }\end{array}$ & Participants & Duration/Format & Agenda \\
\hline October 2019 & $\begin{array}{c}\text { Authors } \\
\text { Company A, B, C, and D }\end{array}$ & $\begin{array}{c}2.5 \mathrm{~h} \\
\text { In-person }\end{array}$ & $\begin{array}{c}\text { Data collection and discussion about IoT } \\
\text { system implementation in each company. }\end{array}$ \\
\hline December 2019 & $\begin{array}{c}\text { Authors } \\
\text { Company A, B, C, and D }\end{array}$ & $\begin{array}{c}2 \mathrm{~h} \\
\text { In-person }\end{array}$ & $\begin{array}{c}\text { Data collection and discussion about IoT } \\
\text { system implementation in each company. }\end{array}$ \\
\hline January 2020 & $\begin{array}{c}\text { Authors } \\
\text { Company A, B, C, and D }\end{array}$ & $\begin{array}{c}2 \mathrm{~h} \\
\text { In-person }\end{array}$ & $\begin{array}{c}\text { Data collection and discussion about IoT } \\
\text { system implementation in each company. }\end{array}$ \\
\hline February 2020 & Authors & $\begin{array}{c}\text { Discussion and development of interview } \\
\text { items concerning the IoT investment } \\
\text { decision, metrics, and implementation. }\end{array}$ \\
\hline
\end{tabular}


Table 3. Cont.

\begin{tabular}{|c|c|c|c|}
\hline $\begin{array}{c}\text { Month/Year of } \\
\text { Interview or Workshop }\end{array}$ & Participants & Duration/Format & Agenda \\
\hline June 2020 & $\begin{array}{c}\text { Authors } \\
\text { Company A, B, C, and D }\end{array}$ & $\begin{array}{l}\text { On-line } \\
\text { e-mail }\end{array}$ & $\begin{array}{l}\text { Preliminary study using the } \\
\text { interview items. }\end{array}$ \\
\hline July 2020 & $\begin{array}{c}\text { Authors } \\
\text { Company A, B, and D }\end{array}$ & $\begin{array}{c}2 \mathrm{~h} \\
\text { On-line }\end{array}$ & $\begin{array}{l}\text { Interview with company A and B. } \\
\text { (One hour, each.) }\end{array}$ \\
\hline August 2020 & $\begin{array}{c}\text { Authors } \\
\text { Company A, B, C, and D }\end{array}$ & $\begin{array}{c}2 \mathrm{~h} \\
\text { On-line }\end{array}$ & $\begin{array}{l}\text { Interview with company C and D } \\
\text { (One hour, each.) }\end{array}$ \\
\hline October 2020 & $\begin{array}{c}\text { Authors } \\
\text { Company A, B, C, and D }\end{array}$ & $\begin{array}{c}2 \mathrm{~h} \\
\text { On-line }\end{array}$ & $\begin{array}{l}\text { Follow-up interview and corrections. } \\
\text { (30 min., each.) }\end{array}$ \\
\hline January 2021 & $\begin{array}{c}\text { Authors } \\
\text { Company A, B, and D. }\end{array}$ & $\begin{array}{c}2 \mathrm{~h} \\
\text { On-line }\end{array}$ & $\begin{array}{l}\text { Presentation from authors (60 min.) and } \\
\text { follow-up interview and corrections. } \\
\text { ( } 20 \text { min., each.) }\end{array}$ \\
\hline May 2021 & $\begin{array}{c}\text { Authors } \\
\text { Company A, B, C, and D }\end{array}$ & $\begin{array}{c}2 \mathrm{~h} \\
\text { On-line }\end{array}$ & $\begin{array}{l}\text { Follow-up interview and corrections. } \\
\qquad(30 \mathrm{~min} ., \text { each. })\end{array}$ \\
\hline September 2021 & $\begin{array}{c}\text { Authors } \\
\text { Company A, B, C, and D }\end{array}$ & $\begin{array}{c}2 \mathrm{~h} \\
\text { On-line }\end{array}$ & $\begin{array}{l}\text { Follow-up interview and corrections. } \\
\text { (15 min., each.) }\end{array}$ \\
\hline
\end{tabular}

\section{Case Analysis and Results}

In this section, the cases of IoT system investment in the companies surveyed are summarized from the following four points: (1) Overview of the IoT system; (2) Approval process for IoT system investment; (3) Effectiveness indicators and criteria at the time of IoT system implementation; (4) Measurement and management of the effects of IoT system investment performance.

\subsection{Company $A$}

\subsubsection{Overview of the IoT System}

The system was implemented in 2019. In conjunction with the construction of a new state-of-the-art smart factory, a system to manage people and objects' movement and equipment status using IoT was established. In addition to the data managed by the previous system, such as person-hours, manufacturing and inspection records, and parts inventory, the new system uses sensors placed at various locations in the factory to collect and aggregate information on facility operation status and workers' traffic lines. This system makes it possible to predict equipment breakdowns and grasp the status of production progress in real-time and in an integrated manner, speeding up the analysis and improvement cycle to improve the efficiency of production activities. Furthermore, by capturing the work of skilled workers and superimposing it on the smart glasses with the information obtained by the sensor to support genba work, it is possible to improve work efficiency significantly.

\subsubsection{IoT System Investment Approval Process}

Depending on the scale of the investment (large-scale, medium-scale, or small-scale), the drafters and final approvers differ. In the case of large-scale investment, the division manager or project leader drafts the proposal, and the president gives final approval. In the case of medium-scale projects, the director or project sub-leader drafts the plan, and the executive officer gives final approval. In the case of small-scale projects, the proposal is drafted by the person in charge and given final approval by the director. The approval process has two stages: the budget and implementation stages.

Regardless of the size of the investment, the criteria for judging the investment is whether it will lead to capacity enhancement (productivity improvement) or not. Especially 
in the case of rationalization/cost reduction, the payback period method is used, and the investment purpose and effect are judged comprehensively.

\subsubsection{Indices of Expected Effects of IoT System Investment}

As a quantitative indicator, Free Cash Flow (FCF) is an important indicator of whether the payback period is within several years. In addition, the improvement of the Cash Conversion Cycle (CCC) is an essential item. According to the IoT investment objectives, quality, cost, and dependability $(\mathrm{QCD})$ are set.

As qualitative indicators, the number of ICT substitutions for technologies and skills that have been dependent on human bodies is measured and evaluated in terms of whether they can be improved or not. With large-scale strategic investments, the managers demand the expensive and latest IoT investments and expect qualitative effects such as "XX times higher productivity compared to conventional processes" or "the latest smart factory that meets customer expectations" are essential conditions.

\subsubsection{Measurement and Management of the Effects of IoT System Investment Performance}

As for the quantitative evaluation, the ERP system reports the amount of effect regularly for reporting to the head of the investment department. In addition, depreciation and amortization are allocated to businesses and products and evaluated in the income statement. Based on the income statement, the effectiveness of the investment is evaluated in terms of return on invested capital (ROIC) and CCC. Qualitative evaluation is managed through regular reports to the head of the investment division.

\subsection{Company $B$}

\subsubsection{Overview of the IoT System}

Company B invested in three IT systems. The first is the factory energy optimization system introduced in 2015. The second is a system for visualizing KPIs in factories introduced in 2018. This system was initially developed and used for one factory but has since been rolled out to all factories. The third is an information platform that links field information with sales, design, manufacturing, and other information to visualize necessary management and KPI information in real-time, which is currently in progress.

\subsubsection{IoT System Investment Approval Process}

Depending on the scale of the investment (large-scale, medium-scale, or small-scale), the drafters and final approvers differ. In the case of large-scale investment, the division manager executing the investment drafts the proposal, and the president gives final approval. In the case of medium-scale, the general manager of the investment execution department drafts the plan, and the department head gives final approval. In the case of small-scale investments, the factory manager or the department's general manager gives final approval.

Regardless of the investment size, the criteria for judging the investment are based on the quantitative and qualitative effects and the investment payback period. There are no restrictions, such as verifying the investment through a committee in advance.

\subsubsection{Indices of Expected Effects of IoT System Investment}

Quantitative indicators include inventory reduction, lead time reduction, productivity improvement, improvement in the ratio of good products, and the degree of reduction in waste costs (costs generated by waste). Qualitative indicators include the visualization of problems, identifying issues in sub-processes and other unclearly controlled processes, the quick response to these issues, the reduction of work-in-process (WIP) and improvement of control level, the reduction of ad hoc operations, and the stabilization of dispersion in quality. 
4.2.4. Measurement and Management of the Effects of IoT System Investment Performance

As a quantitative effect, there has been progress in reducing WIP inventory. In addition, there were cases where productivity was significantly improved and cases where the investment was recovered in a short period due to the early resolution of chronic defects. As a qualitative effect, inventory and problems that would have been invisible if this company had not invested in the IoT system were identified and solved. In addition, the visualization of the entire supply chain can potentially change the recognition of the lead time concept. In addition, this company expected the use of Big Data Analytics and artificial intelligence (AI).

\subsection{Company $\mathrm{C}$}

\subsubsection{Overview of the IoT System}

Company $\mathrm{C}$ invested in two IT systems. The first is a system for production operations introduced in 2019. In conjunction with the renewal of the ERP system, the peripheral systems necessary for production operations were renewed (OEM supply and demand planning management system, production planning system, Kanban system, ERP /MRP system, logistics tracking system). The second is a system for supply management at overseas factories introduced in 2020.

\subsubsection{IoT System Investment Approval Process}

Depending on the scale of the investment (large, medium, or small scale), the decision criteria, drafters, and final approvers differ. In the case of large-scale investment, the executive officer or the general manager drafts the proposal, and the president gives final approval. In the case of medium scale, the general manager drafts the plan, and the executive officer gives final approval. In the case of small-scale investments, there are no specific rules.

In the case of large-scale investments, cost-effectiveness, degree of customer involvement, and strategic importance are used as criteria for judging investments, which require review by the Executive Committee and approval by the IT Committee. In the case of medium-scale investments, the criteria are based on ROI and the degree of customer involvement, which require the approval of the IT Committee. The case of small-scale investment requires the approval of the IT Committee.

\subsubsection{Indices of Expected Effects of IoT System Investment}

Quantitative indicators are not always clearly defined, but the aim is to achieve payback as soon as possible (within a few years). In addition, the ratio of return on investment is used. The following are qualitative indicators: the ability to respond to customer requirements, the upfront investment that leads to business expansion, and investment that eliminates the cost of countermeasures after quality problems occur.

\subsubsection{Measurement and Management of the Effects of IoT System Investment Performance}

In terms of quantitative evaluation, the larger the system or mechanism, the more difficult it is to evaluate, as there are too many business changes to understand the IT system's degree of impact. Therefore, the quantitative effect can be considered the degree of personnel transfer or workforce saving due to organizational changes, including other factors. At the system implementation, confirmation is made as to whether the intended effect was obtained. The quantitative indicators include inventory turnover days, indirect costs, and person-hours. Qualitative evaluations include improvements in planning accuracy and operational quality.

\subsection{Company D}

\subsubsection{Overview of the IoT System}

Company D invested in two IT systems. The first is a product assembly cell system. Multiple sensors are installed in the cell line to check the correctness of the work order 
and the proper screw tightening. This system prevents work errors, and if the work is not performed correctly, an alarm is issued to prevent the subsequent work from being performed, thus creating a "system that prevents the creation of defects". In addition, the entire floor is monitored in real-time by a monitoring system that aggregates the data from the sensors and analyzes the actual production results and operating status of the line in real-time. The second is a system to visualize and diagnose the power environment of the factory. The system visualizes the energy consumption in the factory. Furthermore, it diagnoses the room for energy reduction by installing sensors at the production site, linking and centrally managing the amount of energy used to the quality and productivity targets and results in real-time.

\subsubsection{IoT System Investment Approval Process}

Depending on the scale of the investment (multiple levels depending on the amount), the drafters and final approvers differ. For the highest level, the general manager of the investment execution division drafts the plan, and the president gives final approval. Depending on the level, the general manager of the investment execution division or the organization manager drafts the plan, and the general manager, center manager, division manager, or company group manager gives final approval. Regardless of the investment scale, the criteria for judging the investment are the quantitative and qualitative effects and the investment payback period.

\subsubsection{Indices of Expected Effects of IoT System Investment}

The quantitative indicator is the improvement of QCD. Quality (Q) refers to improving quality (percentage of good products). Cost (C) refers to the improvement of productivity, the improvement of equipment operating rate (reduction of short-time breakdown), and the reduction of WIP inventory. Dependability (D) refers to the reduction of lead time. As qualitative indicators, in terms of production, the IoT system supports workers by automatically displaying work instructions and improving the efficiency of genba kaizen (improvement) activities by visualizing shop floor information. The system performs to prevent defects in input, process, and output in terms of quality.

\subsubsection{Measurement and Management of the Effects of IoT System Investment Performance}

We discuss only the effects of the first system. As a quantitative effect, productivity per worker has been improved by grasping real-time cell line information and improving the worksite. In addition, robots were introduced to save space and workforce in the inspection and packaging processes. As a qualitative effect, the system promoted labor-saving and high-efficiency production by reducing work errors, improving quality, and reducing maintenance costs through labor-saving and predictive management in the inspection process.

\subsection{Comparison on Ex-Ante Evaluation Criteria and Ex-Post Performance of IoT System Investment}

Table 4 shows a comparison of each company's ex-ante evaluation criteria and ex-post performance of IoT system investment. There is a limitation that the specific amount of investment cannot be disclosed publicly due to confidentiality. As seen in Table 4, since the IoT system investments discussed in this study were mainly related to manufacturing sites, it can be said that the evaluation criteria, outcomes, and implementation targets were focused on production activities and factories. Our case study highlights the importance of digital investments in production activities to improve productivity and efficiency and shows the companies' quantitative and qualitative benefits.

In the future, digital investment and IT system investment will be required not only to focus on improving factory efficiency but also to look at other activities more broadly. In other words, when planning, evaluating, and implementing IT system investments for manufacturing activities, it is essential not to limit the investment to production activities but to improve the entire flow of design information to the customer. Implementing IT system 
investments and evaluating them with a "total optimization orientation" is necessary. It is necessary to establish IT system investment activities, strategies, and investment evaluation criteria to coordinate and synthesize how much productivity improvement at the plant level will increase efficiency, effectiveness, and value created in the entire value chain. For this purpose, we need to set the IT investment's purpose clearly and what kind of value can be created and then determine the evaluation criteria, investment decision-making process, and evaluation time horizon suitable for it. These investment objectives and value settings can be called "the concept of IT system investment". The case companies in this paper were all primarily focused on increasing the productivity of workplaces and factories. Such improvements in the capabilities and performance of the workplaces will eventually lead to improved performance of the business unit level and corporate level. In addition, it is crucial to build an IT system that can evaluate and enhance the business's competitiveness and the competitiveness of the operations in the field.

Table 4. Comparison of ex-ante criteria and ex-post performance of IoT system investment.

\begin{tabular}{|c|c|c|c|c|}
\hline & Company A & Company B & Company $\mathrm{C}$ & Company D \\
\hline \multicolumn{5}{|c|}{$\begin{array}{ccr} & \text { (1) Ex-ante criteria of IoT system investment } \\
& \text { Reduce inventory and } & \\
& \text { lead times. } & \\
& \text { Improvement of } & \\
\text { productivity and } & \text { Pay back } \\
\text { Recovery period. } & \text { prediction of } & \text { possible } \\
\text { Improvement in CCC. } & \text { abnormalities. } & \text { few } \\
\text { QCD targets to meet } & \text { Improvement in } & \text { Return on } \\
\text { investment objectives. } & \text { non-defective } & \\
& \text { product ratio. } & \\
& \text { Reduction of } & \\
& \text { wasteful costs. }\end{array}$} \\
\hline $\begin{array}{l}\text { Qualitative } \\
\text { indices }\end{array}$ & $\begin{array}{l}\text { The number of ICT } \\
\text { substitution for } \\
\text { technologies and skills } \\
\text { of humans. } \\
\text { "The productivity will } \\
\text { increase in XX \% } \\
\text { compared to } \\
\text { conventional processes". } \\
\text { "The latest smart plant } \\
\text { that meets customer } \\
\text { expectations". }\end{array}$ & $\begin{array}{l}\text { Visualization and quick } \\
\text { solution of problems. } \\
\text { Reduction of WIP } \\
\text { Reduction of ad } \\
\text { hoc operations. } \\
\text { Stabilization of } \\
\text { dispersion in quality }\end{array}$ & $\begin{array}{l}\text { Responding to } \\
\text { customer requests. } \\
\text { Business expansion. } \\
\text { Preventing quality } \\
\text { problems. }\end{array}$ & $\begin{array}{l}\text { Supports workers by } \\
\text { automatically displaying } \\
\text { work instructions. } \\
\text { Visualization of the effect } \\
\text { of Kaizen activities. } \\
\text { Preventing the defects. }\end{array}$ \\
\hline \multicolumn{5}{|c|}{ (2) Ex-post evaluation and performance of IoT system } \\
\hline $\begin{array}{l}\text { Quantitative } \\
\text { indices }\end{array}$ & $\begin{array}{l}\text { Periodically report } \\
\text { benefits to the head of the } \\
\text { investment division. } \\
\text { Evaluate by business } \\
\text { ROIC and CCC. }\end{array}$ & $\begin{array}{l}\text { WIP reduction. } \\
\text { Productivity. } \\
\text { Improvement in } \\
\text { quality ratio. }\end{array}$ & $\begin{array}{l}\text { Inventory Turn Over. } \\
\text { Indirect Costs. } \\
\text { Person-hours. }\end{array}$ & $\begin{array}{l}\text { Improvement in } \\
\text { productivity per worker. } \\
\text { Saving space and } \\
\text { workforce in the } \\
\text { inspection and } \\
\text { packaging. }\end{array}$ \\
\hline $\begin{array}{l}\text { Qualitative } \\
\text { indices }\end{array}$ & $\begin{array}{l}\text { Manage by regularly } \\
\text { reporting to the head of } \\
\text { the investment division. }\end{array}$ & $\begin{array}{c}\text { Problems could } \\
\text { be solved. } \\
\text { Change in the concept of } \\
\text { lead time. }\end{array}$ & $\begin{array}{l}\text { Improvement of the } \\
\text { planning accuracy. } \\
\text { Improvement of the } \\
\text { quality of operations. }\end{array}$ & $\begin{array}{l}\text { Labor-saving and } \\
\text { high-efficiency } \\
\text { production by reducing } \\
\text { work errors, improving } \\
\text { quality, and reducing } \\
\text { maintenance costs. }\end{array}$ \\
\hline
\end{tabular}

\subsection{Summary of Findings}

The summary of the case study's findings are as follows.

(1) The main objective of the IoT system investment is to improve shop floor operational performance such as quality, productivity, and lead time. These systems include 
manufacturing management dashboards, flow improvement, traceability, automation and labor-saving, visualization of energy-saving effects, and work improvement and training. There is a tendency to focus on streamlining the factory's flow of materials and information. However, few investments aim to improve coordination among plants and streamline the flow of materials and information throughout the supply chain.

(2) Investment in IoT systems has been approved as a strategic investment. The evaluation criteria, conditions, drafters, and final approvers vary depending on the purpose and applications of the investment. Investment criteria, investment size, and KPIs differ depending on whether the investment is recognized as company-wide IT investment or plant-level investment.

(3) Each company uses its own quantitative and qualitative evaluation criteria when making IoT system investment decisions. Investment effects are evaluated based on financial indicators and the degree of improvement in operational performance, such as QCD of production activities.

(4) Because of the difficulty of measuring the effect of IoT system investment, the effect tends to be grasped by easy-to-measure and short-term indicators such as the degree of improvement in operational performance. Our study confirmed that IoT investments were made to utilize the manufacturing capabilities cultivated at the production site. In other words, it can be evaluated that the IoT is functioning as an effective IT system in realizing and supporting a "good flow of good design" at the production site. Since it is not easy to measure and understand the effects of IT system investments, the emphasis tends to be placed on the use of IoT in individual processes rather than on investments to improve the performance of the entire factory or value chain. Therefore, in order to make investments that will improve the flow of the entire factory or value chain, it is necessary to devise suitable indicators for measuring investment effectiveness.

\section{Discussion}

\subsection{Issues in Digitizing the Operations in Japanese Manufacturing Companies}

As a result of continuous discussions on our case study's findings through several workshops attended by practitioners and academics, the following issues were suggested as challenges in the digitization of the shopfloor and IoT system investment in Japanese manufacturing companies.

\subsubsection{Difficulty to Measure the Effect of IoT Systems Investment}

Since the period required for the effects of an IoT systems investment to appear may be extended, uncertainty in the effects of investment also tends to increase. As mentioned above, IoT investment in respondent companies was to utilize the manufacturing capabilities cultivated at the production site. However, the effects of these IT investments are relatively easy to quantify and are measured in the short term. These findings suggest that a critical issue facing Japanese companies is that they cannot fully evaluate the direct effects of their IoT investments based on financial outcomes. As a result, it is not easy for these Japanese companies to obtain satisfactory financial results from their IoT investments and obtain funds for future IoT investments and implementation. Therefore, there is a need for activities and management that can link IoT implementation and investment to financial outcomes.

The IoT systems analyzed in this paper are functioning as effective IT systems [19] in realizing and supporting the "good flow of good design" in production sites [26-28,35-51,64-68]. However, there is a tendency for IoT investment in time-consuming activities such as the transfer of know-how accumulated on the shop floor and human resource development to be postponed and underestimated. As investments in departments and specific activities where the effects are relatively easy to measure are promoted, it may become difficult to implement and justify IT investments that affect the entire factory or value chain. In order to avoid this kind of IT investment that promotes partial optimization, 
it is necessary to recognize and position IoT system investment as a company-wide resource allocation activity.

\subsubsection{Dilemma in IoT System Investment}

The IoT system investment behavior in this paper suggests that it is necessary to consider the relationship between "solving problems and issues faced by the frontline" and "top-down overall optimal investment" [76-83]. The difficulty of this relationship, a dilemma situation, is thought to occur as follows.

(1) First, we assume the following two preconditions. IT investment proposals are drafted close to the frontline, leading to the construction of IT systems directly related to frontline problems. On the other hand, top-down decision-making will lead to constructing a system that facilitates overall optimization.

(2) Next, consider the degree of delegation of authority. Suppose top management asks for IoT investment, and there are no constraints. In that case, the first step is to implement IoT investment that can promote improvement activities that are troubling the company daily, where effects can be easily seen in a relatively short period. In the decision-making process of drafting and implementing such IT investments that promote problem-solving in the field, the opinions of the genba must be reflected. At the same time, it is necessary to show that the investment in IT systems is effective in the short term in an easy-to-understand manner because there is a possibility that the investment will be scaled down (or stopped) if it does not produce effects in the field. On the other hand, a large-scale investment can be made by a top-down order. However, suppose such investment is not based on an accurate understanding of the actual capabilities and problems of the worksite. In that case, the constructed IT system will be "a system that is difficult for the worksite to use". As a result, it will not be easy to create the targeted value and will not be fully utilized for worksite improvement.

(3) From the above, even if the field is empowered, if the evaluation criteria for investment effectiveness is short-term and focus on the rate of improvement of field operations, IT investment will be narrowly focused on solving problems that can be solved immediately. On the other hand, even if cross-departmental investment in total optimization by top-down, if the IT system is not directly related to the solution of problems in the field and does not fit the manufacturing capabilities, it will be difficult to use in the field. As a result, "customization" will proceed to the form that is easy to use in each department, division, and site, and coordination among IT systems used within the company will not proceed well. In addition, when trying to link up with the ERP system used as a global standard, for example, customization frequently occurs to fit the work style of the field, and unique subsystems are created to demonstrate the strengths of each department, resulting in poor system-wide linkage. The result is that the system does not work well. In this case, even though the system is designed to reduce the workload on the shop floor and facilitate the coordination of information across various departments, the result is that it promotes individual optimization and increases the workload of each department.

(4) As described above, if the investment in IoT systems is delegated to the shop floor, the systems will be easy to use in the field. However, it will be difficult to connect them, and they will fall into partial optimization. On the other hand, if we proceed in a top-down manner, the system will be difficult to use in the field if it cannot be adequately implemented. This approach will increase individual customization, even if the investment is made for a system that aims for total optimization. As a result, interdepartmental coordination does not work well, and the system falls into individual optimization. How can we solve this kind of dilemma?

(5) To solve this dilemma, it is necessary to reconsider the purpose of IoT system in-vestment in the first place, what the "ideal" state of the company's manufacturing is, and how to confirm that this state is being realized. Of course, if the objective is to "improve operations at the production site", it has already been confirmed that excellent indicators 
and measurement methods have been established and used in practice with high results, as clarified in this paper. However, what kind of metrics and investment behaviors will optimize the entire value chain? From the perspective of digital investment accompanied with business model transformation, IT investment aimed at improving the efficiency of manufacturing sites alone is not sufficient. In that case, large-scale, top-down investment decisions will be necessary. In doing so, it is necessary to devise evaluation criteria, set a particular time horizon (several years) and scale (large-scale ICT investment associated with new factory construction), and proceed with investment decision-making from a broad, long-term perspective. In other words, it is necessary to clarify how IT system investment should be made in a way that promotes both the strategic investment for creating new customer value and the utilization and enhancement of existing organizational capabilities.

In order to solve the problems described in this section, it is necessary to improve the methods and KPIs for understanding the results of IoT system investment [60-63]. However, it is not easy to identify whether the performance improvement in production activities is due to the direct effect of IoT system investment or other factors. This difficulty may be caused by our study investigating the operationally excellent sites of Japanese companies. Since these Japanese production sites have continuous improvement activities, these companies have highly efficient operational capabilities. Therefore, for example, if the productivity of factory increases to a certain level in some period, and IT system investment is made simultaneously, it is not easy to separate the effect of the organizational capability and the effect of the introduction of the IT system on the result of this productivity increase. In other words, the more experience a company has in improving efficiency based on good teamwork and know-how in the field, the more difficult it is to understand the direct effects of IT system investment. It is also necessary to devise an evaluation method that can accurately distinguish between the two and understand these complementary effects.

Where it is difficult to measure the effects of an investment in IoT systems, it is assumed that there will be an increasing tendency for investment in IoT systems to be limited to the use of IoT in individual processes rather than to improve the performance of the entire factory or value chain. IoT and ICT investments are expected to function as an infrastructure to improve the entire value chain's efficiency and create customer value. However, since it is difficult to grasp the effects of such investments, they will be applied to processes where the effects are easy to understand. Therefore, it is necessary to evaluate the impact of the investment activities, if practical, and reconsider them as an issue for top management, rather than letting the investment activities start individually in the field. In order to make IoT investments that will improve the flow of the entire factory or value chain, it is necessary to devise suitable indicators to measure the investment effects.

\subsection{Analytical Framework for Elucidating the Decision-Making Process and Investment Effects of IoT System Investments}

This paper identified the following factors as influencing IoT system investment activities in the digitalization of operations: "IoT system concept and positioning" (purpose of investment, strategic significance), "IoT investment approval process" (IT investment project personnel's resource acquisition behavior), and "IoT investment evaluation criteria" (performance evaluation indicators, time frame for understanding and evaluating effectiveness). Based on the case study, this paper constructs and proposes an analytical framework for comprehensively clarifying the relationship among IoT system investment decision-making, organizational capabilities (IT system capability, operational capability), and investment effects, as shown in Figure 1. A comprehensive analysis of the relationship between the purposes, evaluation criteria, decision-making process, and performance of IoT system investments is important in practice and academic research. As shown in Figure 1, interdepartmental coordination, organizational capability, and IoT utilization capability are assumed to affect the relationships between the investment in IoT systems and their results [26-28,37-56,64-68]. 


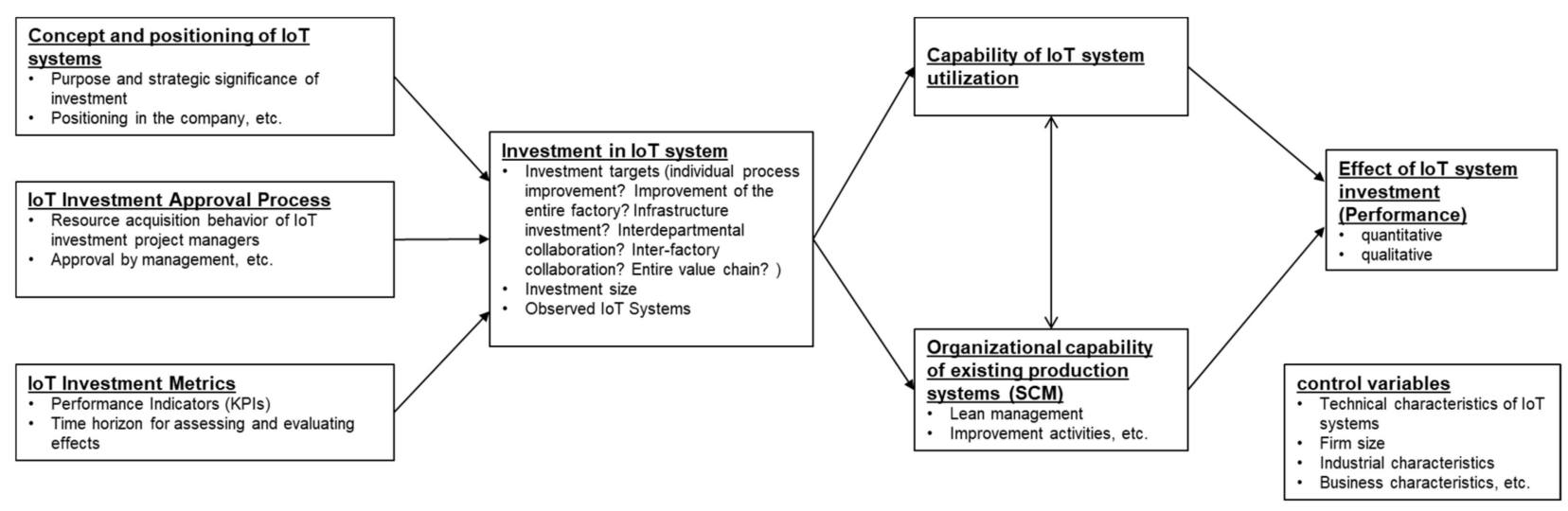

Figure 1. An analytical framework elucidating the relationship among decision-making, organizational capabilities, and effect of IoT system investment.

This analytical framework needs to be refined through qualitative and quantitative research. It will be possible to visualize the actual state of field operations and grasp the effects of an investment in individual IoT systems by collecting detailed production improvement data and their performance. Concerning organizational theory, it is possible to explore the relationship between the nature of the investment project organization, the impact of the organizational design on IoT system investment activities (decision-making, evaluation criteria, etc.), and the resulting investment performance [76-83]. In addition, concerning strategic management theory, IoT system investment activities will be viewed as a resource allocation and resource acquisition process [85]. It will be possible to analyze IoT system investment as a process innovation that utilizes digital technology and market creation. More specific research subjects are assumed as follows.

(1) Investigation on the causal relationship among "investment, introduction, and utilization of IoT systems", "improvement of manufacturing capabilities (individual departments and activities, cross-functional coordination, and supply chain management)", and "improvement of operational performance (QCDF)".

(2) What are the differences in the evaluation criteria according to the setting and selection of the scope of the "flow" to be covered (individual process, intra-factory, SCM, inter-company, etc.)? What are the differences between KPIs used at production sites and those used at headquarters and accounting departments, and how do they relate to each other? What evaluation criteria should be created and how (short-term/long-term results, quantitative/qualitative)? Who determines the evaluation criteria, and through what process? What should be the target domain? (Single business/multiple businesses, individual department/cross-functional, etc.). How is the linkage between evaluation and resource allocation made?

(3) What are the objectives of IoT system investment? How do suitable evaluation criteria and KPIs differ according to the envisioned objectives of the investment (e.g., improving the efficiency of field operations, increasing SCM efficiency, increasing customer value, improving the profitability of existing businesses, creating new businesses, etc.)? How to utilize the "unused resources" [86] generated by digitization (e.g., aiming to introduce digital technologies and use data to create new products and businesses)?

(4) How do we solve the interdepartmental/ cross-functional coordination problem (partial and total optimization)? The "differentiation and integration" in the organization is a classical but new issue [87]. For example, if we know that the "silo" organization does not work well, why is it difficult to change them? Is this a top management problem or a problem of organizational design and incentives? How can we improve efficiency by using IT in each function (production, purchasing, development, sales, and logistics), and how can we create an IT system that promotes cross-functional collaboration and collaboration between genba and headquarters? 
(5) In searching for solutions to the above problems, what is the most effective relationship between company-wide efforts and the efforts of each business unit or manufacturing site? How should the areas commonly evaluated and controlled by the head office and the areas to be evaluated and determined by each business unit with autonomy be set? How should the scope of authority and responsibility of the organization promoting digitization be set?

\subsection{Exploring the Management of Value Flow That Leverages Digitalization}

It is becoming increasingly essential to visualize the flow of goods and information across a wide range of global activities and quickly identify and solve problems. Japanese manufacturing companies are also actively introducing and utilizing digital technologies such as IoT and AI to grasp the flow of materials and information within factories and across the entire global supply chain. In order to understand this flow, many Japanese companies try to collect a large amount and variety of data (e.g., information on the operating status and defects of factories of the company and its suppliers, information on the progress of production and distribution, order information, etc.).

However, although the "flow of materials and information" in production activities is good with IT and IoT, there remains a problem of how to coordinate among functions, departments, and companies. For example, the scholars in [20] found that IT systems are not sufficiently integrated across departments; although the same IT systems are used, the operation methods differ among departments.

With the rapid development of digital technology since the 2000s, it has become possible to collect, process, analyze, and communicate diverse and massive amounts of data beyond the constraints of time and space and beyond the physical limitations of human beings. As this trend intensifies, the challenge of managing the diverse and massive flow of "things" and "information" across various departments is increasing. Who should take the lead in promoting the "total optimization" of the flow, and how should it be coordinated? Who should take the lead, and how should it be coordinated? These are the questions that need to be considered in the era of Industry 4.0, Smart Factory, and digital transformations.

Essentially, digital technology is expected to improve the flow of "information" and make it easier to achieve total optimization. However, there is a possibility that the use of digital technology will promote partial optimization, resulting in a "dysfunction of the flow improving technology" [88] where conflicts between departments worsen. Interdepartmental barriers in the organization may be more prominent than technological barriers as factors that impede the information flow. When the value flows within and between organizations change due to digitization in the factory, the organizational coordination might be difficult and crucial.

Digital technology is a "tool", and the introduction of advanced technology will not be efficient or necessarily produce better results if the team/organization does not have the skills to utilize it. What should be undertaken to link a series of activities from development, production, sales, and marketing using digital technology and expand and create business through these activities? How can we make the most of our accumulated organizational capabilities and resources? What kind of "technology" can solve the various coordination problems among individuals, teams, companies, and global locations? Research and practical efforts that can answer these questions will be necessary.

\section{Conclusions}

This study conducted an exploratory case analysis of Japanese manufacturing companies to identify the actual status of investment activities in IoT systems and the essential common issues. The study also showed that IoT investments in Japanese companies improve production activities' efficiency. However, collaboration among divisions and departments other than production is not sufficient. 
Furthermore, this paper also contributes to constructing an analytical framework for comprehensively clarifying IoT system investment decision-making and investment effects. Based on this framework, it became clear that differences in the positioning of IoT system investment within the company, the intended performance indicators, and the time horizon for grasping investment effects may have affected each company's IoT system investment behavior and their outcome. Under the current evaluation criteria and investment process, there is a tendency to focus on IoT system investments that are relatively easy to understand and produce visible results, such as those directly related to improving production site performance. These investments have effectively improved manufacturing activities' "flow of materials and information". However, from the perspective of "optimizing the flow of materials and information in the entire value chain", further study is needed to determine whether IoT system investments based on these evaluation indicators and methods will lead to the desired effects. In other words, it is simultaneously necessary that "steadily problem-solving on the shop floor by using digital technology" and "investment in IoT systems from the standpoint of total optimization" improve the flow of materials and information throughout the factory and value chain. Developing decision-making methods and investment evaluation criteria for IoT system investment is necessary to make this possible.

In Japan, the long-term trend is for the working population to decline, and a shortage of workers has become an urgent issue at many production sites. In this situation, if no action is taken, the shortage of workers may lead to the factory's closure as it will not be able to produce the required amount of goods, resulting in the loss of employment in the factory's area. In order to cope with such a labor shortage, unless operations are digitized in a way that can utilize the existing strengths of the factory, IT and equipment investment will increase in undesirable ways. As a result, it will become difficult to maintain production activities, and the performance of companies will deteriorate. If the labor force continues to decline, digitalization of operations through IoT investment and implementation, as analyzed in this paper, will be one of the most effective measures to make production activities and supply chains sustainable. As revealed in this paper, manufacturing sites in Japan have been digitizing their production sites by promoting IoT implementation.

Appropriate promotion of digitalization in factories will also make it possible to improve work efficiency, streamline production lines, and reduce defective products and inventories [37-59]. These will maximize the products and added value while minimizing the waste of parts and materials. As a result, the earth's limited resources will be effectively utilized, contributing to reducing the environmental load. Furthermore, when unexpected crises occur, such as various disasters or outbreaks of infectious diseases, operations will be disrupted that rely heavily on human work. Therefore, as discussed in this paper, promoting the digitalization of operations through IoT investments is essential to make production activities and supply chains sustainable in situations where human mobility is limited.

As mentioned above, it is essential to enhance the sustainability of production activities and supply chains by adapting to various risks, such as natural disasters, infectious diseases, and a declining labor force [1-7]. For this purpose, IoT implementation and digitalization of operations are effective means. In order to promote the IoT implementation and digitization of operations, this paper has made an important contribution by elucidating the metrics and performance indicators necessary to effectively manage the decision-making and execution of IoT implementation, based on comparative case studies of several Japanese companies. The paper has provided useful suggestions for companies facing similar situations.

The limitations of this study are as follows. First, since the number of surveyed companies is small, it is necessary to pay attention to the generalizability of the results obtained from the case study analysis. Second, due to the spread of COVID-19, we could not conduct field observation at the companies' factories, so the data used in the case study analysis in this paper is limited to interview results and secondary sources. Therefore, it is necessary to supplement the information about how the IoT system operates in the 
companies' factories and how the IoT system and workers cooperate in the factory by conducting field surveys when the infection has settled down.

The following are future research directions. First, construct measurement scales for IoT investment effectiveness and empirical analysis on Japanese companies. Second, investigate the differences in countries/regions, business models, and business/industry characteristics to IoT system investment decisions, IoT implementations, and their outcomes. Finally, quantitative studies may test the analytical framework using larger samples. We expect to empirically clarify the relationship between IT system investment, organizational capabilities (lean production, supply chain management), and performance. Furthermore, it will be helpful to analyze the investment in IoT and IT systems to create customer value and optimize the entire value chain by linking it to the discussion on digital transformation.

Author Contributions: M.F., R.S., Y.P. and J.S. contributed equally for the paper. All authors have read and agreed to the published version of the manuscript.

Funding: This research received no external funding.

Institutional Review Board Statement: Not applicable.

Informed Consent Statement: Not applicable.

Data Availability Statement: The authors confirm that the data supporting the findings of this study are available within the article.

Conflicts of Interest: The authors declare no conflict of interest.

\section{References}

1. Braunscheidel, M.J.; Suresh, N.C. The organizational antecedents of a firm's supply chain agility for risk mitigation and response. J. Oper. Manag. 2009, 27, 119-140. [CrossRef]

2. Fujimoto, T.; Park, Y.W. Balancing supply chain competitiveness and robustness through "virtual dual sourcing": Lessons from the great east Japan earthquake. Int. J. Product. Econ. 2014, 147, 429-436. [CrossRef]

3. Hong, P.; Park, Y.W. Rising Asia and American Hegemony: Practices of Global Firms from Japan, Korea, China and India; Springer: Singapore, 2020.

4. Park, Y.W.; Hong, P.; Roh, J.J. Supply chain lessons from the catastrophic natural disaster in Japan. Bus. Horiz. 2013, 56, 75-85. [CrossRef]

5. Singh, N.; Hong, P. Impact of strategic and operational risk management practices on firm performance: An empirical investigation. Eur. Manag. J. 2020, 38, 723-735. [CrossRef]

6. Fujimoto, T. A Research note on global supply chains in the after-COVID-19 era. MMRC Discuss. Paper Ser. 2020, 533, 1-20.

7. Shih, W.C. Global supply chains in a post-pandemic world. Harv. Bus. Rev. 2020, 98, 82-89.

8. Holmström, J.; Holweg, M.; Lawson, B.; Pil, F.K.; Wagner, S.M. The digitalization of operations and supply chain management: Theoretical and methodological implications. J. Oper. Manag. 2019, 65, 728-734. [CrossRef]

9. Koh, L.; Orzes, G.; Jia, F. The fourth industrial revolution (Industry 4.0): Technologies disruption on operations and supply chain management. Int. J. Oper. Prod. Manag. 2019, 39, 817-828. [CrossRef]

10. Ortt, R.; Stolwijk, C.; Punter, M. Implementing Industry 4.0: Assessing the current state. J. Manuf. Technol. Manag. 2020, 31, 825-836. [CrossRef]

11. Ivanov, D.; Tang, C.S.; Dolgui, A.; Battini, D.; Das, A. Researchers' perspectives on Industry 4.0: Multi-disciplinary analysis and opportunities for operations management. Int. J. Prod. Res. 2021, 59, 2055-2078. [CrossRef]

12. Kipper, L.M.; Furstenau, L.B.; Hoppe, D.; Frozza, R.; Iepsen, S. Scopus scientific mapping production in industry 4.0 (2011-2018): A bibliometric analysis. Int. J. Prod. Res. 2020, 58, 1605-1627. [CrossRef]

13. Liao, Y.; Deschamps, F.; de Freitas Rocha Loures, E.; Ramos, L.F.P. Past, present and future of Industry 4.0-A systematic literature review and research agenda proposal. Int. J. Prod. Res. 2017, 55, 3609-3629. [CrossRef]

14. Piccarozzi, M.; Aquilani, B.; Gatti, C. Industry 4.0 in management studies: A systematic literature review. Sustainability 2018, 10, 3821. [CrossRef]

15. Savastano, M.; Amendola, C.; Bellini, F.; D’Ascenzo, F. Contextual impacts on industrial processes brought by the digital transformation of manufacturing: A systematic review. Sustainability 2019, 11, 891. [CrossRef]

16. Yin, Y.; Stecke, K.E.; Li, D. The evolution of production systems from Industry 2.0 through Industry 4.0. Int. J. Prod. Res. 2018, 56, 848-861. [CrossRef]

17. Borregan-Alvarado, J.; Alvarez-Meaza, I.; Cilleruelo-Carrasco, E.; Garechana-Anacabe, G. A Bibliometric analysis in Industry 4.0 and advanced manufacturing: What about the sustainable supply chain? Sustainability 2020, 12, 7840. [CrossRef] 
18. Kalsoom, T.; Ahmed, S.; Rafi-ul-Shan, P.M.; Azmat, M.; Akhtar, P.; Pervez, Z.; Imran, M.A.; Ur-Rehman, M. Impact of IoT on manufacturing Industry 4.0: A new triangular systematic review. Sustainability 2021, 13, 12506. [CrossRef]

19. Fujimoto, T.; Park, Y.W. Monozukuri Utilizing IT; Nihon Keizai Shinbun Shuppansha: Tokyo, Japan, 2015. (In Japanese)

20. Fukuzawa, M.; Sugie, R.; Park, Y.W.; Shi, J. Empirical study of IT system utilization in value chain: A case study of four manufacturing firms. J. Jpn. Oper. Manag. Strategy 2020, 10, 18-34. (In Japanese)

21. Yin, R.K. Case Study Research and Applications: Design and Methods, 6th ed.; Sage Publications: Thousand Oaks, CA, USA, 2018.

22. Maghazei, O.; Netland, T. Implementation of Industry 4.0 Technologies: What can we learn from the past? In Advances in Production Management Systems: The Path to Intelligent, Collaborative and Sustainable Manufacturing; Lödding, H., Riedel, R., Thoben, K.D., von Cieminski, G., Kiritsis, D., Eds.; Springer: Cham, Switzerland, 2017; Volume 513, pp. 135-142. [CrossRef]

23. Nosalska, K.; Piatek, Z.M.; Mazurek, G.; Rządca, R. Industry 4.0: Coherent definition framework with technological and organizational interdependencies. J. Manuf. Technol. Manag. 2020, 31, 837-862. [CrossRef]

24. Zheng, T.; Ardolino, M.; Bacchetti, A.; Perona, M. The applications of Industry 4.0 technologies in manufacturing context: A systematic literature review. Int. J. Prod. Res. 2021, 59, 1922-1954. [CrossRef]

25. Moeuf, A.; Pellerin, R.; Lamouri, S.; Tamayo-Giraldo, S.; Barbaray, R. The industrial management of SMEs in the era of Industry 4.0. Int. J. Prod. Res. 2018, 56, 1118-1136. [CrossRef]

26. Buer, S.-V.; Strandhagen, J.O.; Chan, F.T.S. The link between Industry 4.0 and lean manufacturing: Mapping current research and establishing a research agenda. Int. J. Prod. Res. 2018, 56, 2924-2940. [CrossRef]

27. Pagliosa, M.; Tortorella, G.; Ferreira, J.C.E. Industry 4.0 and Lean Manufacturing. J. Manuf. Technol. Manag. 2021, 32, 543-569. [CrossRef]

28. Riezebos, J.; Klingenberg, W.; Hicks, C. Lean Production and information technology: Connection or contradiction? Comput. Ind. 2009, 60, 237-247. [CrossRef]

29. Osterrieder, P.; Budde, L.; Friedli, T. The smart factory as a key construct of industry 4.0: A systematic literature review. Int. J. Product. Econ. 2020, 221, 107476. [CrossRef]

30. Strozzi, F.; Colicchia, C.; Creazza, A.; Noè, C. Literature review on the 'Smart Factory' concept using bibliometric tools. Int. J. Prod. Res. 2017, 55, 6572-6591. [CrossRef]

31. Aryal, A.; Liao, Y.; Nattuthurai, P.; Li, B. The emerging big data analytics and IoT in supply chain management: A systematic review. Supply Chain Manag. 2020, 25, 141-156. [CrossRef]

32. Ben-Daya, M.; Hassini, E.; Bahroun, Z. Internet of things and supply chain management: A literature review. Int. J. Prod. Res. 2019, 57, 4719-4742. [CrossRef]

33. Chauhan, C.; Singh, A. A review of Industry 4.0 in supply chain management studies. J. Manuf. Technol. Manag. 2020, 31, 863-886. [CrossRef]

34. Palmaccio, M.; Dicuonzo, G.; Belyaeva, Z.S. The internet of things and corporate business models: A systematic literature review. J. Bus. Res. 2021, 131, 610-618. [CrossRef]

35. Womack, J.P.; Jones, D.T.; Roos, D. The Machine that Changed the World: Based on the Massachusetts Institute of Technology 5-Million Dollar 5-Year Study on the Future of the Automobile; Rawson Associates: New York, NY, USA, 1990.

36. Holweg, M. The genealogy of lean production. J. Oper. Manag. 2007, 25, 785-805. [CrossRef]

37. Cagliano, R.; Canterino, F.; Longoni, A.; Bartezzaghi, E. The interplay between smart manufacturing technologies and work organization. Int. J. Oper. Prod. Manag. 2019, 39, 913-934. [CrossRef]

38. Cimini, C.; Boffelli, A.; Lagorio, A.; Kalchschmidt, M.; Pinto, R. How do industry 4.0 technologies influence organisational change? An empirical analysis of Italian SMEs. J. Manuf. Technol. Manag. 2021, 32, 695-721. [CrossRef]

39. Cottyn, J.; Van Landeghem, H.; Stockman, K.; Derammelaere, S. A method to align a manufacturing execution system with Lean objectives. Int. J. Prod. Res. 2011, 49, 4397-4413. [CrossRef]

40. Hermann, M.; Bücker, I.; Otto, B. Industrie 4.0 process transformation: Findings from a case study in automotive logistics. J. Manuf. Technol. Manag. 2020, 31, 935-953. [CrossRef]

41. Kamble, S.; Gunasekaran, A.; Dhone, N.C. Industry 4.0 and lean manufacturing practices for sustainable organisational performance in Indian manufacturing companies. Int. J. Prod. Res. 2020, 58, 1319-1337. [CrossRef]

42. Khanchanapong, T.; Prajogo, D.; Sohal, A.S.; Cooper, B.K.; Yeung, A.C.L.; Cheng, T.C.E. The unique and complementary effects of manufacturing technologies and lean practices on manufacturing operational performance. Int. J. Product. Econ. 2014, 153, 191-203. [CrossRef]

43. Kolberg, D.; Knobloch, J.; Zühlke, D. Towards a lean automation interface for workstations. Int. J. Prod. Res. 2017, 55, 2845-2856. [CrossRef]

44. Kolberg, D.; Zühlke, D. Lean Automation enabled by Industry 4.0 Technologies. IFAC-PapersOnLine 2015, 48, 1870-1875. [CrossRef]

45. Powell, D.; Alfnes, E.; Strandhagen, J.O.; Dreyer, H. The concurrent application of lean production and ERP: Towards an ERP-based lean implementation process. Comput. Ind. 2013, 64, 324-335. [CrossRef]

46. Roscoe, S.; Cousins, P.D.; Handfield, R. The microfoundations of an operational capability in digital manufacturing. J. Oper. Manag. 2019, 65, 774-793. [CrossRef]

47. Szász, L.; Demeter, K.; Rácz, B.-G.; Losonci, D. Industry 4.0: A review and analysis of contingency and performance effects. J. Manuf. Technol. Manag. 2021, 32, 667-694. [CrossRef] 
48. Tortorella, G.; Sawhney, R.; Jurburg, D.; de Paula, I.C.; Tlapa, D.; Thurer, M. Towards the proposition of a Lean Automation framework. J. Manuf. Technol. Manag. 2021, 32, 593-620. [CrossRef]

49. Tortorella, G.L.; Cawley Vergara, A.M.; Garza-Reyes, J.A.; Sawhney, R. Organizational learning paths based upon industry 4.0 adoption: An empirical study with Brazilian manufacturers. Int. J. Product. Econ. 2020, 219, 284-294. [CrossRef]

50. Tortorella, G.L.; Fettermann, D. Implementation of Industry 4.0 and lean production in Brazilian manufacturing companies. Int. J. Prod. Res. 2018, 56, 2975-2987. [CrossRef]

51. Veile, J.W.; Kiel, D.; Müller, J.M.; Voigt, K.-I. Lessons learned from Industry 4.0 implementation in the German manufacturing industry. J. Manuf. Technol. Manag. 2020, 31, 977-997. [CrossRef]

52. Banker, R.D.; Bardhan, I.R.; Chang, H.; Lin, S. Plant Information Systems, Manufacturing Capabilities, and Plant Performance. Manag. Inf. Syst. Q. 2006, 30, 315-337. [CrossRef]

53. Heim, G.R.; Peng, D.X. The impact of information technology use on plant structure, practices, and performance: An exploratory study. J. Oper. Manag. 2010, 28, 144-162. [CrossRef]

54. Ward, P.; Zhou, H. Impact of Information Technology Integration and Lean/Just-In-Time Practices on Lead-Time Performance. Decis. Sci. 2006, 37, 177-203. [CrossRef]

55. Ghobakhloo, M.; Hong, T.S. IT investments and business performance improvement: The mediating role of lean manufacturing implementation. Int. J. Prod. Res. 2014, 52, 5367-5384. [CrossRef]

56. Tortorella, G.L.; Giglio, R.; van Dun, D.H. Industry 4.0 adoption as a moderator of the impact of lean production practices on operational performance improvement. Int. J. Oper. Prod. Manag. 2019, 39, 860-886. [CrossRef]

57. Boehmer, J.H.; Shukla, M.; Kapletia, D.; Tiwari, M.K. The impact of the Internet of Things (IoT) on servitization: An exploration of changing supply relationships. Prod. Plan. Control 2020, 31, 203-219. [CrossRef]

58. De Vass, T.; Shee, H.; Miah, S. IoT in Supply Chain Management: Opportunities and Challenges for Businesses in Early Industry 4.0 Context. Oper. Supply Chain Manag. 2021, 14, 148-161. [CrossRef]

59. Rymaszewska, A.; Helo, P.; Gunasekaran, A. IoT powered servitization of manufacturing-An exploratory case study. Int. J. Product. Econ. 2017, 192, 92-105. [CrossRef]

60. Ante, G.; Facchini, F.; Mossa, G.; Digiesi, S. Developing a key performance indicators tree for lean and smart production systems. IFAC-PapersOnLine 2018, 51, 13-18. [CrossRef]

61. Hwang, G.; Lee, J.; Park, J.; Chang, T.-W. Developing performance measurement system for Internet of Things and smart factory environment. Int. J. Prod. Res. 2017, 55, 2590-2602. [CrossRef]

62. Kamble, S.S.; Gunasekaran, A.; Ghadge, A.; Raut, R. A performance measurement system for industry 4.0 enabled smart manufacturing system in SMMEs- A review and empirical investigation. Int. J. Product. Econ. 2020, 229, 107853. [CrossRef]

63. Shin, W.S.; Dahlgaard, J.J.; Dahlgaard-Park, S.M.; Kim, M.G. A Quality Scorecard for the era of Industry 4.0. Total Qual. Manag. Bus. Excell. 2018, 29, 959-976. [CrossRef]

64. Aral, S.; Weill, P. IT Assets, Organizational Capabilities, and Firm Performance: How Resource Allocations and Organizational Differences Explain Performance Variation. Organ. Sci. 2007, 18, 763-780. [CrossRef]

65. Bharadwaj, A.S. A Resource-Based Perspective on Information Technology Capability and Firm Performance: An Empirical Investigation. Manag. Inf. Syst. Q. 2000, 24, 169-196. [CrossRef]

66. Mithas, S.; Tafti, A.; Bardhan, I.; Goh, J.M. Information Technology and Firm Profitability: Mechanisms and Empirical Evidence. Manag. Inf. Syst. Q. 2012, 36, 205-224. [CrossRef]

67. Neirotti, P.; Paolucci, E. Industry and firm effects on IT diffusion processes: Firm-level evidence in Italian enterprises. Ind. Corp. Chang. 2013, 23, 717-757. [CrossRef]

68. Santhanam, R.; Hartono, E. Issues in linking information technology capability to firm performance. Manag. Inf. Syst. Q. 2003, 27, 125-153. [CrossRef]

69. Devaraj, S.; Rajiv, K. Performance impacts of information technology: Is actual usage the missing link? Manag. Sci. 2003, 49, 273-289. [CrossRef]

70. Bosman, L.; Hartman, N.; Sutherland, J. How manufacturing firm characteristics can influence decision making for investing in Industry 4.0 technologies. J. Manuf. Technol. Manag. 2020, 31, 1117-1141. [CrossRef]

71. Buer, S.-V.; Strandhagen, J.W.; Semini, M.; Strandhagen, J.O. The digitalization of manufacturing: Investigating the impact of production environment and company size. J. Manuf. Technol. Manag. 2021, 32, 621-645. [CrossRef]

72. Dewan, S.; Shi, C.; Gurbaxani, V. Investigating the risk-return relationship of information technology investment: Firm-level empirical analysis. Manag. Sci. 2007, 53, 1829-1842. [CrossRef]

73. Dong, J.Q.; Karhade, P.P.; Rai, A.; Xu, S.X. How firms make information technology investment decisions: Toward a behavioral agency theory. J. Manag. Inf. Syst. 2021, 38, 29-58. [CrossRef]

74. Lee, I.; Lee, K. The Internet of Things (IoT): Applications, investments, and challenges for enterprises. Bus. Horiz. 2015, 58, 431-440. [CrossRef]

75. Schwartz, E.S.; Zozaya-Gorostiza, C. Investment under uncertainty in information technology: Acquisition and development projects. Manag. Sci. 2003, 49, 57-70. [CrossRef]

76. Boonstra, A. Structure and analysis of IS decision-making processes. Eur. J. Inf. Syst. 2003, 12, 195-209. [CrossRef]

77. Frisk, J.E.; Lindgren, R.; Mathiassen, L. Design matters for decision makers: Discovering IT investment alternatives. Eur. J. Inf. Syst. 2014, 23, 442-461. [CrossRef] 
78. Love, P.E.D.; Irani, Z. An exploratory study of information technology evaluation and benefits management practices of SMEs in the construction industry. Inf. Manag. 2004, 42, 227-242. [CrossRef]

79. Love, P.E.D.; Irani, Z.; Standing, C.; Lin, C.; Burn, J.M. The enigma of evaluation: Benefits, costs and risks of IT in Australian small-medium-sized enterprises. Inf. Manag. 2005, 42, 947-964. [CrossRef]

80. Neirotti, P.; Paolucci, E. Assessing the strategic value of Information Technology: An analysis on the insurance sector. Inf. Manag. 2007, 44, 568-582. [CrossRef]

81. Weill, P. Don't just lead, govern: How top-performing firms govern IT. MIS Q. Exec. 2004, 3, 1-17.

82. Weill, P.; Olson, M.H. Managing Investment in Information Technology: Mini Case Examples and Implications. Manag. Inf. Syst. Q. 1989, 13, 3-17. [CrossRef]

83. Xue, Y.; Liang, H.; Boulton, W.R. Information Technology Governance in Information Technology Investment Decision Processes: The Impact of Investment Characteristics, External Environment, and Internal Context. Manag. Inf. Syst. Q. 2008, 32, 67-96. [CrossRef]

84. Eisenhardt, K.M. Building theories from case study research. Acad. Manag. Rev. 1989, 14, 532-550. [CrossRef]

85. Burgelman, R.A. Strategy is Destiny: How Strategy-Making Shapes a Company's Future; Free Press: New York, NY, USA, 2002.

86. Penrose, E.T. The Theory of the Growth of the Firm; Basil Blackwell: Oxford, UK, 1959.

87. Lawrence, P.R.; Lorsch, J.W. Organization and Environment: Managing Differentiation and Integration; Harvard Business School Press: Cambridge, MA, USA, 1967.

88. Fukuzawa, M. Reconsideration of value stream mapping and cross-functional integration in the digitalization of operations. Ann. Bus. Adm. Sci. 2020, 19, 263-276. [CrossRef] 